\title{
Religionsvidenskab, klassifikation og kontekst
}

\author{
Af Kasper Graarup
}

\section{Indledning}

De sidste 50 års relativistiske og pragmatiske bølge har medført at de fleste $i$ dag ville argumentere for at viden $i$ høj grad er af subjektiv natur og at forskellige mennesker på forskellige tider ville opfatte viden forskelligt (Grauballe et al., 1998, 18f)

Dette citat udtrykker en udbredt moderne opfattelse af hvad viden er for noget. Viden opfattes ikke mere som noget der kan bestemmes objektivt og endeligt, men derimod som noget dynamisk og subjektivt. Sådan har det ikke altid været: Uanset om vi taler om filosofisk klassifikation eller om bibliografisk klassifikation er videnskabshistorien rig på fors $\emptyset \mathrm{g}$ på en gang for alle at samle alverdens viden i et kohærent og entydigt system. Et illustrativt eksempel på denne stræben leverer Borges (1990, 11-14) i en artikel, der kan betragtes som et opgør med idéen om et én til én forhold i relationen mellem signifiant og signifiés, mellem det der repræsenterer og det der repræsenteres. Borges kommer ind på forskellige fors $\emptyset \mathrm{g}$ på at udvikle ,naturlige sprog“, hvilket vil sige sprog der er bygget op efter matematiske logiske princip- per, og hvor hvert enkelt udtryk refererer til en enkelt og kun én entitet ude i verden. Som led i argumentationen for at denne bestræbelse har sine klare begrænsninger nævnes Det Bibliografiske Institut i Bruxelles, hvor man har inddelt universet i 1000 underkategorier: ,... nummer 262 tilkommer paven; nummer 282 den romersk-katolske kirke; nummer 263 Herrens dag; nummer 268 søndagsskolerne; nummer 298 mormonismen og nummer 294 brahmanismen, buddhismen, shintoismen og taoismen" (Borges 1990, 13) ${ }^{1}$, og det påpeges hvorledes et sådan system uvægerligt løber ind i om ikke andet så i hvert fald hvad vi i klassifikationsteori vil kalde redundans ${ }^{2}$. Som et særlig spektakulært eksempel på det futile i bestræbelsen efter universalitet refererer Borges til en kinesiske encyklopædi med den velsignelsesrige og lovende titel: De godgørende kundskabers himmelske skatkammer, hvori dyrene inddeles som følger:

(a) dem der tilhører kejseren, (b) de balsamerede, (c) de tamme, (d) pattegrise, (e) havfruer, (f) fabeldyr, (g) løse hunde, (h) dem som er inkluderet i denne klassifikation, (i) dem der hidser sig op som vanvittige, (j) dem som findes i stor mæng- 
de, (k) dem som er tegnet med en fin kamelhårspensel, (l) osv., (m) dem der lige har slået vasen itu, (n) dem der på afstand ligner uer

Den kinesiske encyklopædi virker absurd, hvilket er det samme som at sige at den harmonerer meget dårligt med vore implicitte eller eksplicitte forestillinger - teorier - om verdens beskaffenhed i relation til zoologien. Vi vil nok med Borges bestride at disse klasser skulle re ektere en universel repræsentation af arternes distribution. Hvad der derimod turde være tydeligt er at dette klassifikationssystem er ganske overordentligt historisk og kulturelt bundet. Hermed ikke være sagt at systemet ikke i sin egen samtid og sammenhæng kan have været ganske funktionelt, nærmere tværtimod. Disse klasser er ikke meningsfulde for os og det fordi systemet forekommer os inkonsistent og ,ulogisk“. En udgave af samme system som vi ikke ville tage umiddelbart anstød af kunne tage sig således ud:

(a) dem der tilhører kejseren,

(b) dem der ikke tilhører kejseren,

(b1) dem der tilhører kejserens kone,

(b2) dem der tilhører kejserens børn.

Her udgør ejerskab klassifikationsprincippet. Vi kunne også vælge at sortere efter begravelsesskik, og kunne således med udgangspunkt i klassen (b) de balsamerede, fortsætte med

(c) de jordfæstede, (d) de brændte, (e) de fortærede osv.

Hermed ville vi have tilført systemet en konsistens der selvsagt ville kunne diskuteres, men som under alle omstændigheder i langt højere grad ville afspejle de klasser og systemer vi sædvanligvis tænker i. Birger Hjørland (1993) argumenterer for at et givent informationssystem bør udformes i henhold til de erkendelsesinteresser, der er kendetegnende for den kontekst inden for hvilken informationssystemet skal fungere. Skulle vi tage encyklopædien alvorligt og i henhold til Hjørlands teori om erkendelsesinteresser, og ved en slags inverteret domæneanalyse ana- lyserer os frem til systemets (encyklopædien) ideelle kontekst, ville idealbrugeren ikke kunne være nogen anden end den enevældige, forkælede, megalomane og idiosynkratiske kinesiske kejser selv: Han sidder i sit palads og tænker naturligvis først og fremmest i kategorien „hvad tilhører mig“, og hvad af det der tilhører mig er ,balsameret“" (hedengangen), og hvad er ,tamt“ (underforstået hvad bider ikke i kejserens fingre når han rækker ud efter det). Klassen ,,pattegrise" er et udtryk for kejserens selvfølgelige appetit på livet, og ligeledes ,havfruerne“, der i ere betydninger pirrer kejserens lyst. Klasserne har i det hele taget kejseren som verdens eneste og naturlige centrum, som verdens eneste parameter hvilket tydeligt ses i den sidste kategori ,dem der på afstand ligner uer": Set fra det kejserlige vindue er det det eneste af betydning der er at sige om disse dyr. Denne udlægning forekommer rimeligvis lidt søgt, men den vil være i overensstemmelse med ovenfor citerede beskrivelse af viden som værende ,,af subjektiv natur og at forskellige mennesker på forskellige tider ville opfatte viden forskelligt".

I denne skildring af kejserens forhold til klassifikationssystemet kan begrebet „subjektiv“ opfattes som værende individuelt og psykologisk bestemt, og det er det da også i den betydning at det er lige præcis kejseren og ingen anden der tages udgangspunkt $i$, men det bringer os ikke nødvendigvis - i dette tilfælde - på kollisionskurs med et mere sociologisk orienteret udgangspunkt: I denne vor forestilling om det imperiale Kina er det jo nemlig således, at kejserens personlige idiosynkrasier er menigmands objektive virkelighed: Den dagsorden kejseren sætter udgør den verden undersåtten lever i. Kejser og menigmand har så at sige de samme opfattelser af, hvad der er op og ned, hvad der godt og ondt, hvad der smager godt og hvad der smager dårligt. Det betyder at vi (i denne ideale forestilling om det imperiale Kina) kan generalisere den psykologisk analyse af kejserens verdensopfattelse til at gælde for hele det kinesiske folk - det psykologiske og sociologiske har i dette tænkte eksempel altså samme dimensioner. Således er det ikke i Danmark i dag: Dronningens normer (for at blive inden for det royale og 
lettere overdrevne) er ikke nødvendigvis identiske med de autonomes fra Nørrebro ditto. De danske folkebibliotekers klassifikationssystem DK5 er et (national-) universelt klassifikationssystem, der ideelt set betjener såvel dronning som autonom. Mener man dette muligt (ved encyklopædiens monorepræsentationelle ${ }^{3}$ metodik) må det enten bero på den antagelse at begges erkendelsesinteresser er irrelevante i forhold til den objektive repræsentation af bibliotekets materialer, eller omvendt på den (vulgær-) kognitivistiske antagelse at det på baggrund af en grundig undersøgelse af dronningens kognitive habitus ville være muligt at identificere alment menneskelige mentale mønstre og den dertil hørende informationssøgningsadfærd. En viden der følgelig ville kunne generaliseres til at gælde ikke blot den autonome, men den menneskelige race $\mathrm{i}$ almindelighed. Min opfattelse er på linie med Hjørland den, at viden om brugernes erkendelsesinteresser er relevante for repræsentationen af bibliotekets materialer, og at disse erkendelsesinteresser identificeres ved sociologiske frem for psykologiske metoder: I Almen Semiotik hvor Borges tekst er trykt efterfølges denne af et uddrag af Lakoffs Women, Fire and Dangerous Things (1987). I dette uddrag demonstrerer Lakoff med reference dels til Borges' kinesiske encyklopædi og dels til R.M.W. Dixon's socio-lingvistiske undersøgelser af det australske urfolk Dyirbal at selv de klassifikationssystemer, der umiddelbart virker absurde, hviler på såvel universelle som kulturspecifikke principper, der i det $\varnothing j$ jeblik vi bliver bekendt med disse gør at systemerne kan genkendes som velbegrundede i forhold til den sammenhæng de indgår i. Lakoffs eksempel er netop titlen på bogen, nemlig kvinder, ild og farlige ting. Kvinder, ild og farlige ting tilhører samme klasse. Til denne klasse hører også pungharer, hunde, nogle slanger, nogle fisk, de este fugle, ild uer, skorpioner, fårekyllinger, lodne larver med brod, skjolde, nogle spyd, stjerner, solen og meget andet, og så begynder vi at nærme os noget der ligner Borges' kinesiske encyklopædi. At netop disse ting klassificeres sammen kan forklares med udgangspunkt i fire begreber nemlig solen, kvinder, ild og farlige ting: I Dyirbal mytologi er solen månens hustru, ergo er solen af hunkøn. Det er kvinder også, hvorfor solen og kvinder kommer i samme kategori. Det er dagligdags Dyirbal erfaring at lys og varme kommer fra solen og fra ilden. Ergo er også ilden i denne klasse. Ild er farlig, hvorfor farlige ting generelt kommer i denne klasse. Således lyder forklaringen og heri skjuler sig - påstås det - en række såvel universelle som kulturspecifikke forhold. Det universelle er for Lakoff noget, der kan konstateres i det menneskelige kognitive apparat, i den menneskelige måde at tænke, subsidiært klassificere på. Til disse universelle klassifikationsprincipper hører sammenkcedning. Klasser opstår ved sammenkædning således forstået at hvis solen, kvinder, ild og farlige ting er i samme klasse, da er det ikke eksempelvis fordi disse i Dyirbal bevidsthed formodes at besidde en mængde fælles karakteristika, men netop fordi de er bundet sammen ved associative kæder: Sol som er hunkøn koedes til kvinde, og sol der giver varme koedes til ild, der er farlig og som derved koedes til andre farlige ting etc. Et andet universelt klassifikationsprincip er erfaringsområdets princip: Klassifikationssystemet afspejler det klassificerende folks daglige erfaring. Også dette princip slår tydeligt igennem i anførte eksempel: At solen og ilden er kilder til varme og lys, og at ilden er farlig er dagligdags Dyirbal erfaring. Et tredje universelt princip er den specielle videns princip. Dette princip betoner, at en speciel viden tenderer mod at slå tydeligere igennem i systemet end en generel viden. Et eksempel der ikke i fuldt omfang er synligt i anførte eksempel kunne være, at solen og månen er placeret $\mathrm{i}$ hver sin klasse, og ikke som man måske kunne have forventet på baggrund af en generel viden om disse som begge tilhørende "klassen" af himmellegemer (anførselstegnene da Dyirbal ikke har en klasse for himmellegemer). Den specielle viden der i dette tilfælde overskriver den generelle viden om himmellegemer, er en mytologisk viden om solen og månen som ægtefolk, og som dermed værende af forskellige køn. Det er denne viden der slår igennem i systemet, og det gør den bl.a. i kraft af det sidste universelle princip, der skal nævnes, nemlig kønnet. Som vi let kan overbevise os om ved blot et øjeblik at betænke de indoeuropæiske sprogs grammatik - det er ikke så tydeligt i dansk, men derimod særdeles tydeligt $\mathrm{i}$ 
eksempelvis tysk - er kønnet et ganske udbredt klassifikationsprincip. Det er ligeledes universelt at hankøn optræder umarkeret i forhold til hunkøn, hvilket vil sige at en sætning, der ikke ekspliciterer kønnet underforstår hankøn, mens hunk $ø$ n skal ekspliciteres for at blive opfattet.

Således anskueliggør Lakoff, at det tilsyneladende absurde er båret af en både meningsfuld og universelt genkendelig logik. Den i de traditionelle universelle klassifikationssystemer forudsatte universalitet er altså ikke med Lakoff aldeles udryddet, men snarere erstattet: Borges demonstrerer det uholdbare $\mathrm{i}$ forestillingen om evige, objektive og universelle kategorier, og Lakoff respondere ved at erkende dette, men også ved at argumentere for at kulturel forskellighed ikke desto mindre bygger på universelle kognitive principper. Universaliteten er altså bevaret, blot udtrykker den ikke mere objektive egenskaber ved (signifiés) det klassificerede univers, men ikke mindre objektive egenskaber ved (signifiant) det klassificerende subjekt. Denne bevægelse fra at fokusere på det beskrevne til i stedet at fokusere på det beskrivende er også kendetegnende for LIS i dag, og kommer til udtryk ved det at studier i klassifikation må opgive sine objektive og universalistiske ambitioner til fordel for brugerstudier, og lige præcis denne erkendelse er jo også, hvad "the cognitive revolution" refererer til: Sammen med prætentionerne om objektiv universalisme falder jo også maskinparadigmet (det fysikalistiske paradigme, systemorientering etc.), og ud af ruinerne vokser brugeren - mennesket og studiet af menneskelige kognitive processer.

\section{Filosofisk klassifikation og bibliografisk klassifi- kation}

Dixon's socio-lingvistiske unders $\emptyset$ gelser af Dyirbal og Lakoffs applikation af samme demonstrerer altså at man via domæne analyse - i dette tilfælde sociolingvistiske, antropologiske studier - kan få indblik i folks måder at tænke på, at vidensorganisere på. Som sådan kan Dixon og Lakoff inddrages i en argumentation for Hjørland, der i sin doktordisputats bl.a. skriver at ,informationsvidenskaben studerer vidensdomæner med henblik på at kunne optimere overføringen, udnyttelsen og formidlingen af viden“" (Hjørland, 1993, 141). Diverse klassifikationssystemer er en del af det apparat biblioteks- og informationsvidenskaben betjener sig af i sine bestræbelser på at ,optimere overføringen, udnyttelsen og formidlingen af viden“, og har Hjørland ret, betyder dette følgelig at studiet af vidensdomæner fører til erkendelser, der bør have en afsmittende virkning på også klassifikation, og det er da også et synspunkt der hersker nogenlunde enighed om - i hvert fald i teorien: Det er således nogenlunde selvfølgeligt at et givent vidensdomænes eller fagområdes karakteristika bør have en afsmittende virkning på det informationssystem - herunder klassifikationssystem - der beskæftiger sig med „overføring, udnyttelse og formidling“ af de for det pågældende fag relevante dokumenter, men der hersker ingen enighed om præcis hvad denne afsmitning består i, eller hvordan den operationaliseres i forbindelse med design og evaluering af informationssystemer. Det er eksempelvis et almindeligt synspunkt i LIS at filosofisk klassifikation og bibliografisk klassifikation ikke behøver at være forbundne (Grauballe et al. 1998, 17f). Dette udsagn kan opfattes på ere ikke gensidigt udelukkende måder, der afhænger af hvad der forstås ved filosofisk klassifikation: Forstår man filosofisk klassifikation som en filosofisk bestræbelse på at udvikle et objektivt, universelt og entydigt klassifikationssystem - således som Borges parodierer - bør et sådan projekt alene i kraft af sin åbenbare umulighed ikke in uere på udvikling af diverse bibliografiske klassifikationssystemer. Som sådan er jeg ganske enig i at henholdsvis filosofisk og bibliografisk klassifikation ikke behøver være forbundne. Forstår man derimod, som jeg, filosofisk klassifikation som værende (i denne sammenhæng) identisk med videnskabelig klassifikation, i.e. med diverse videnskabelige domæners eksplicitte og implicitte måder at organisere viden på, da finder jeg tværtimod at det vil være særdeles hensigtsmæssigt at lade filosofisk og bibliografisk klassifikation være forbundne.

Jeg vil gerne bruge resten af denne artikel til at argu- 
mentere for netop det 1) at filosofisk og bibliografisk klassifikations børe være forbundne og for at det der forbinder dem kan identificeres ved domæneanalyse, og på 2) at forholde mig kritisk til den almindelige opfattelse af videns subjektive natur: Viden er muligvis subjektiv, men det er en subjektivitet, der er kontekstuel, og en subjektivitet der snarere bestemmes ved sociologiske end ved psykologiske metoder.

\section{Antropologi og klassifikation}

Den ovenfor omtalte bog Women, Fire and Dangerous Things er fra 1987, men Lakoff er langt fra den første, der har beskæftiget sig med fjerne og eksotiske folks måder at tænke og klassificere på. Antropologer, etnografer, religionsforskere o.a. har siden slutningen af det 19. århundrede, hvor opdagelsen af asiatiske, afrikanske og amerikanske såkaldte primitive folk, i kombination med Darwins banebrydende opdagelser, afstedkom stor interesse for disse fremmede kulturer, fors $\emptyset \mathrm{gt}$ at forklare og forstå disse fjerne folks sæder og skikke. Den oprindelige antropologiske interesse var af historisk karakter, idet de ,primitive“ primært blev studeret i overensstemmelse med Darwins evolutionistiske projekt, hvor opgaven ganske enkelt bestod $\mathrm{i}$ at placere disse folk på rette plads i den menneskelige evolutionære udvikling fra abe til victoriansk gentleman. Denne evolutionistiske dagsorden lod sig af forskellige grunde efterhånden erstatte af en funktionalistisk dagsor$\operatorname{den}^{4}$. At de evolutionære teorier gled i baggrunden skyldes ere ting, men en væsentlig årsag var, at det viste sig overordentlig vanskeligt at påvise den formodede lineære og evolutionære udvikling, teorierne forudsatte. Mere almindeligt blev det efterhånden at opfatte udvikling ikke som lineær, men snarere som noget der lader sig karakterisere ved mere eller mindre uforudsigelige forandringer. Idéen om udvikling erstattedes altså af idéen om forandringer, og heri ligger jo også kimen til at man opgiver sine prætentioner om at fremhæve en kultur på en anden kulturs vegne: Når der ikke kan være tale om evolutionær udvikling, men blot om vilkårlig forandring, da må man også opgive idéen om at en kultur er bed- re end en anden. Kulturer er ikke mere henholdsvis primitive (,dårlige“) og civiliserede (,gode“), men slet og ret forskellige. Interessen begyndte således at koncentrerer sig dels om studiet af enkelte kulturer, og dels af sammenlignende kulturstudier, men altså en sammenligning der ikke var evolutionær (og diakron), men blot komparativ (og synkron). Det funktionalistiske bestod kort fortalt $\mathrm{i}$ at man interesserede sig for det enkelte samfunds respektive institutioners (religion, retsvæsen, familiestrukturer etc.) funktion i og for samfundet som helhed: Hvordan bidrog de enkelte institutioner til samfundets fortsatte beståen? Et klassisk eksempel (der dog og selv sagt er fra før funktionalismen slog igennem i antropologien) er Karl Marx' teori om religion som opium for folket: Religionens funktion var at bedøve masserne for derved at forhindre arbejderklassen i oprør, og således er religionens funktion at sikre den eksisterende orden. Den funktionalistiske tilgang havde og har et stort forklaringspotentiale: Det er eksempelvis uomgængeligt at religion i mange sammenhænge har denne samfundsbevarende og stabiliserende funktion. Problemet for funktionalismen består i at religion ligeså ofte kan have den modsatte funktion, således som det eksempelvis kom til udtryk i det daværende Sovjetunionen, hvor religionen på mange måder var i opposition til styret, der jo forstod sig selv som bl.a. marxistisk, og som dermed forstod religion i en marxistisk betydning, som noget menneske- og samfundsfjendsk. Funktionalismen kan altså meget vel beskrive hvordan en institution i en given sammenhæng har en bestemt funktion, og for så vidt også hvordan en tilsvarende institution i en tilsvarende sammenhæng kan have en helt anden funktion, men funktionalismen kan ikke forklare, hvorfor tingene fungerer, som de gør. Funktionalismen kan eksempelvis sandsynliggøre, at religion har en undertrykkende funktion, men den kan ikke forklare, hvorfor mennesker lader sig undertrykke af religion. Funktionalismen kan ikke forklare, hvorfor lige netop denne religiøse konstruktion og ikke en anden i en given sammenhæng opleves som meningsfuld, og funktionalismen erstattes i løbet af (groft sagt) 1950erne af studier i hvorledes mening opstår. Humanistiske og samfundsvidenskabelige studier i dag 
kan da også i vid udstrækning karakteriseres som studier i hvorledes mening opstår og transmitteres. En delmængde af disse studier er - som Lakoffs overvejende kognitivt orienterede, hvilket vil sige, at de ikke i så høj grad (som det ellers stadig er trenden inden for humaniora) koncentrerer sig om hermeneutiske analyser af kulturelle systemer/entiteter, men at de koncentrerer sig om studiet af menneskets måder at tænke, herunder at klassificere på. Spørgsmålet er således i vores sammenhæng det spørgsmål også Lakoff stiller, nemlig hvorfor én måde at klassificere på er meningsfuld og en anden ikke.

\section{Kategorial versus situeret klassifikation}

Ingwersen $(1992,128 f)$ argumenterer for at man i opbygningen af informationssystemer bør tage hensyn til lige såvel, hvad han kalder kategorial klassifikation som til situeret (eng. situational) klassifikation. Til illustration af hvad der menes med disse begreber refereres til A.R. Luria (1976) og dennes undersøgelser af „klassifikation i en social kontekst". Lurias eksperimenter stammer fra 30erne og er foretaget blandt nomader i det centrale asien. Luria viste nomaderne billeder af fire genstande, eksempelvis hammer, træ, sav og økse, og opfordrede dem til at klassificere genstandene, hvilket ville sige at redegør for hvilke og hvordan de hænger sammen, og for hvilke genstande der eventuelt ikke hører med $^{5}$. Kategorial klassifikation postuleres at betegne det, at „forsøgspersonerne“ identificerer et abstrakt begreb og så sorterer og fravælger de viste genstande i henhold hertil. Kategorial klassifikation viste sig at være typisk for dem med ere år i skolesystemet. De ville eksempelvis fravælge „træ“ og gruppere de resterende genstande under (det abstrakte begreb) værktøj. Under et forsøg i Danmark fravalgtes, efter et ligeledes kategorialt princip, saven, idet de resterende grupperedes som ,genstande med træ [egenskaber]" (Ingwersen, 1992, 129). Situeret klassifikation kaldes en type klassifikation, der tager udgangspunkt i en konkret situation, som f.eks. det at fabrikere brænde: Her vælges hammeren fra og de tre $\varnothing$ vrige grupperes $\mathrm{i}$ henhold til den konkrete (arbejds-) situation. Tilsvarende kan $\emptyset$ ksen vælges fra og de $\varnothing$ vrige grupperes i henhold til snedkerfaget. Blandt nomader var der også eksempler på at alle fire klassificeredes sammen, idet de udgjorde en normal arbejdssituation: Deres træ var nemlig så hårdt, at de ofte brugte hammeren til at slå på $\emptyset \mathrm{ksen}$, når der skulle hugges brænde. Ingwersens pointe er, at man i udviklingen af informationssystemer bør være opmærksom på såvel kategoriale klassifikationsprincipper som på de situerede principper, der nu engang må gøre sig gældende i den respektive kontekst. Situeret klassifikation er et fornuftigt begreb, hvorimod jeg er mere betænkelig ved den kategoriale klassifikation. Begrebets holdbarhed forudsætter, at det blot betegner én type situeret klassifikation, nemlig den type klassifikation, der er situeret i traditionelle bibliografiske klassifikationsprincipper, og således er situeret i en helt konkret faglig erfaring/ tradition. Opfattes begrebet nemlig som situationsuafhængigt vedhæftes det uvægerligt nogle objektivistiske konnotationer om begrebernes egentlige sammenhæng i modsætning til erfaringsområdernes vilkårlige sammenhæng.

Situeret klassifikation ligner til forveksling Lakoffs klassifikation i henhold til erfaringsområdets princip, idet Lakoff jo demonstrerer, at det er den konkrete erfaring (situation) der determinerer hvorledes diverse ting og begreber klassificeres. Ligeledes er såvel situeret klassifikation som erfaringsområdets princip tæt forbundne med de erkendelser, der ligger til grund for Hjørlands domæneteori: Det er analysen af de respektive og konkrete videnskabelige domæner, der udgør den situation, den erfaring i henhold til hvilken informationssystemet konstrueres. Forestiller man sig Lurias metoder overført til en unders $\varnothing$ gelse foretaget blandt det videnskabelige personale på et teologisk fakultet ville billeder, der gengav en fader (Faderen), en søn (Sønnen), en helligånd (Helligånden) og et spøgelse antageligvis grupperer sig således, at de tre første kædedes sammen $\mathrm{i}$ henhold til den dagligdags erfaringen med konstellationen Faderen, Sønnen og Helligånden, medens spøgelset ville blive sorteret fra. Et eksempel på hvad Ingwersen kalder kategorial klassifikation ville i dette tilfælde være, hvis faderen og sønnen 
var grupperet sammen, som repræsentationer af abstraktionen „familierelationer“, medens helligånden og spøgelset sorteredes under abstraktionen ,immaterielle organismer". Sidstnævnte ville ikke være relevant $\mathrm{i}$ en tesaurus for teologer (uden interesse for humanistisk forskning), men den ville være overordentlig relevant $\mathrm{i}$ en tesaurus for religionsvidenskabsfolk, og i særdeleshed for religionsfænomenologer, der nemlig studerer religiøse fænomener komparativt og på tværs af kulturelle sammenhænge. Der foretages eksempelvis sammenlignende analyser af bryllupsritualer i diverse kulturer eller man foretager sammenlignende analyser af ,,immaterielle organismer“, eventuelt defineret som „overnaturlige væsener der formidler kontakt mellem denne og en hinsides verden“. Til denne klasse hører „Helligånden“, der jo blandt andet formidler kontakten mellem Gud og Maria. Diverse „forfædre“ fra de såkaldte primitive samfund ${ }^{6}$ kan også have denne formidlende funktion, og det samme gælder de „medier“, der i visse moderne alternative sammenhænge påstår at kunne skabe kontakt til en afdød slægtning. Pointen er at klassen ,,immaterielle organismer" ikke er mere kategorial end klassen „Faderen, Sønnen og Helligånden“, den er blot udtryk for en anden situerethed, nemlig klassifikation situeret $i$ et religionsfænomenologisk domæne.

\section{Repræsentation og misrepræsentation}

Det religionsfænomenologiske eksempel er ikke et tilfældigt valg $\mathrm{i}$ forhold til aktuelle problemer med eksempelvis DK5 ${ }^{7}$. Og ej heller problematiseringen af begrebet kategorial klassifikation. W.A. Paden $(1992,76)$ skriver i en kritik af religionsfænomenologien, at sammenlignende analyser af religiøse forestillinger og praksiser selv sagt handicappedes noget, hvis forskeren kun kender til en religion, eller hvis forskeren henter alle sine begreber og klassifikationsprincipper fra én kontekst, og så tror sig berettiget til med udgangspunkt i disse begreber at bedrive komparative analyser af også andre religioner. Andre religioner der forstår sig selv i henhold til andre begreber og principper. En sådan praksis kan meget let resulterer i misrepræsentation. Misrepræ- sentation forstået som en repræsentation, der ikke er i overensstemmelse med de inden for domænet gældende antagelser. Padens eksempel er endnu et eksempel fra zoologien: Kender vi kun et dyr, nemlig katten, virkelig godt, og opererer vi samtidig med en forestilling om katten som det idealtypiske dyr, vil vore begreber om andre dyr lide herunder. F.eks. vil hunde, fisk og zebraer i dette klassifikationssystem optræde som henholdsvis ,store katte“, "katte uden ben der svømmer" og ,gigantiske katte med brede striber". Oversat til DK5 og en religionsvidenskabelig sammenhæng kan vi konstatere, at kristendom forholder sig til andre religioner nogenlunde (om end ikke helt så grotesk) som katten til andre dyr. Ligeledes opfattes religionsvidenskab som mere eller mindre identisk med religionsfænomenologi. At kristendommen har en fremtrædende plads i DK5 har naturligvis sine gode grunde. Det er velbegrundet $i$ henhold til såvel efterspørgsel som i henhold til den mængde litteratur der står på hylderne, at kristendommen på de danske folkebiblioteker fylder meget, også i forhold til andre religioner. Men det er også problematisk. F.eks. er der ingen kategorial eller i $\emptyset$ vrigt nødvendighed, der tilsiger, at det vi forstår som religion sorteres i henhold til kristendommen. Der er så at sige ingen objektive grunde til at operere med klassen ,religion“ overhovedet. Det kræver en forklaring: At operere med klassen "religion" er naturligvis velbegrundet i den forstand, at "religion" fungerer som et alment anerkendt begreb, og i den forstand at der findes videnskabelige domæner, der studerer religion. Men det er netop i den forstand, at det er velbegrundet, og ikke i henhold til en objektiv, abstrakt eller kategorial egenskab ved de studerede fænomener i sig selv. Det videnskabelige studie af religion eller rettere af religioner forudsætter, at der er gode grunde til at klassificere og studere netop disse fænomener under ét. En sådan begrundelse kunne være den, der er forsøgt illustreret ved eksemplet med katten, nemlig den at kristendom (katten) er den ideelle og egentlige religion, og at de andre kan studeres som mere eller mindre vellykkede variationer heraf. Således ville det være en forudsætning at et begreb som tro, der uomgængeligt er centralt for protestanter, også ville have en central betydning i 
alle andre religiøse universer, men det er ikke tilfældet. Vi behøver for så vidt ikke at bevæge os længere væk end til katolicismen for at konstatere at de handlingsorienterede (ritualer) sider af religionsud$\emptyset$ velsen fylder mindst ligeså meget. Heller ikke det forhold der er selvfølgeligt i en dansk sammenhæng, nemlig at kristendommen - religionen - som institution betragtet er så let at afgrænse fra andre institutionelle sammenhænge som eksempelvis statsmagten, gælder ubetinget i andre kulturer. Det bedste eksempel herpå er islam, der sådan som vi kender den fra bl.a. Iran, er en uadskillelig del af netop statsmagten. I henhold til dette faktum vil det være mindst ligeså velbegrundet at placere litteratur om islam under samfundsvidenskab eller under de respektive landes kultur og historie, og omvendt formidler vi ved at placere islam i klassen religion en opfattelse af islam som noget, der på linie med kristendommen, kan adskilles fra samfundets $\emptyset$ vrige institutioner. Når det alligevel er fornuftigt med klassen religion, er det som sagt fordi, denne klasse er situeret $i$ en konkret faglig erfaring. Denne faglige erfaring består i en række videnskabelige praksiser og i en række teorier om religion. Faren for misrepræsentation opstår når og hvis den respektive klasse afspejler en teori, der ikke længere har nogen gyldighed. Teorien om zebraer som gigantiske katte er en teori uden gyldighed. Teorien om islam som mere eller mindre identisk med kristendommen er en teori uden gyldighed. Ugyldighed er som sagt når teorierne er inkompatible med de almindeligt fungerende erkendelsesinteresser inden for det område teorien antages at forholde sig til ${ }^{8}$. DK5 gruppe 29 hviler på en teori om religion, der er om ikke ugyldig så i hvert fald betænkelig og under alle omstændigheder mangelfuld. Denne teori er religionsfænomenologien. Religionsfænomenologien blev i sin traditionelle form bedrevet af forskere som Rudolf Otto, Mircea Eliade og G. van der Leeuw og hvilede på den antagelse, at religioner og religiøse fænomener kunne sammenlignes tværkulturelt, i det fænomenerne alle besad de samme essentielle egenskaber. Katte, hunde, fisk og zebraer kunne studeres komparativt, i det de alle blot var vilkårlige variationer over essensen kat. Problemerne er indlysende: Studerer vi zebraen udfra den forudfattede idé, at zebraen blot er en slags kat, ser vi kun det, der bekræfter vore oprindelige antagelse, og bliver ikke klogere på, hvad zebraen eventuelt kunne have af ikke katteagtige egenskaber. Studerer vi ,ånder" med den forudfattede idé, at disse blot er variationer over temaet ,overnaturlige væsener der formidler kontakt mellem denne og en hinsides verden“, får vi ikke øje på den helt specielle værdi eksempelvis Helligånden har i en kristen kontekst etc. Religionsfænomenologien har leveret substantielle bidrag til religionsforskningen og forskellige tidssvarende udgaver af religionsfænomenologien kan for så vidt stadig gøre det, men religionsfænomenologien lider under, at den komparative tilgang ikke i tilstrækkeligt omfang formår at inddrage de enkelte fænomeners kontekst. Religionsvidenskaben i almindelighed er da også i dag langt mere og andet end fænomenologi: Religionsvidenskaben i dag inkluderer metoder og teorier hentet fra historie, sociologi, lingvistik, psykologi, antropologi, etnografi og filosofi (samt en mere tværvidenskabelige tilgang som den ,kognitive“), hvilket tydeligt afspejler sig i den religionsvidenskabelige litteratur. Ikke desto mindre kan vi i DK5 systematikken læse at i gruppe 29.1: Sammenlignende religionsvidenskab sættes „,religionsfænomenologien, den tværgående betragtning af religiøse data og emner". I DK5 opfattes religionsvidenskab altså som værende identisk med religionsfænomenologi, og religionsfænomenologien opfattes som en (neutral) „,betragter“" af ,data“, og ikke som den rettelig er, nemlig en teori, der konstruerer (mere eller mindre velbegrundede) typologier og begreber.

\section{Eksempler på fravær}

Dette forhold har betydelige konsekvenser, da megen relevant religionsvidenskabelig litteratur ikke finder vej til gruppe 29.1, og dermed ved sit fravoer medvirker til at folkebibliotekerne formidler en udgave af religionsvidenskaben, der ikke er realistisk, og ikke modsvarer den aktuelle religionsvidenskabelige teoridannelse, og ej heller den aktuelle religionsvidenskabelige produktion af bøger. Mest misvisende er det nok at de antropologisk og sociolo- 
gisk orienterede religionsteorier findes andre steder i DK5 systemet. Begrundelsen herfor er antageligvis den, at man har opfattet religionsfænomenologien som den centrale religionsvidenskabelige teori, og eksempelvis religionssociologien (gruppe 16.3) som sekundær. Den religionsvidenskabelige virkelighed i dag er en anden: Det er ikke alle religionsvidenskabelige teorier, der er eksplicit religionssociologiske, men (praktisk talt) alle religionsvidenskabelige publikationer tager udgangspunkt i ,mennesket i en social kontekst", hvorfor fraværet af religionssociologiske værker giver et meget forkert billede af religionsvidenskaben. Et af de værker der findes i gruppe 16.3 (uden biplacering) er antologien Religiøse Minoriteter (Kristensen, 1987). Dette værk indeholder artikler med titler som „Temaer i religiøse minoritets/majoritetsforhold“, „Kulturmødet med Islam“, „Verdensbilleder og teoridannelser i religionssociologien“, og „Om ægteskabsindgåelse, anerkendelse af trossamfund og religionsfrihed i Danmark“. Alle er eksempler på centrale religionsvidenskabelige emner og problemer, der altså undgår blikket for den, der ,græsser" omkring gruppe 29.1. Ej heller ville denne „,græsser" finde værket om han søgte på emnetallet 29.1, og ville vedkommende forsøge sig med kontrollerede emneord ville følgende fire give pote „religiøse minoriteter“, „konference rapporter“, „mindretal“ og „religionssociologi“, medens eksempelvis „,religionsvidenskab“, „religionsteori“ eller „Islam“ ikke ville tilvejebringe dette værk. Et andet eksempel på det samfundsteoretiske fravær er Niklas Luhmanns Sociale systemer (2000). Dette værk er oplagt samfundsvidenskabeligt, hvorfor den faktiske placering i gruppe 30.1 (sociologi i alm.) er absolut rimelig. Problemet er at Luhmann er en af de nyere forskere, hvis arbejder, på linie med værker af eksempelvis Anthony Giddens og Jürgen Habermas, har haft central betydning for en bred vifte af human- og samfundsvidenskabelige teorier. Luhmann og dennes teorier om sociale systemer er følgelig en uomgængelige ingrediens i den aktuelle religionsvidenskabelige debat. Et optimalt fungerende informationssystem burde være i stand til at tilvejebringe sine brugere de relevante dokumenter, men en bruger der søger ,aktuelle religionsviden- skabelige teorier" ville med udgangspunkt i DK5 ikke kunne finde frem til Luhmann'.

Men det er ikke kun sociologien, der glimrer ved sit fravær. En anden væsentlig trend i human- og samfundsvidenskaberne er kognitionsforskningen. Bodil Klausen har skrevet en bog der hedder Religion og kognition (1999). Dette værk introducerer til og diskuterer aktuelle kognitivt orienterede religionsteorier, og er ligesom værket Religiøse minoriteter placeret i gruppe 16.3 (religionssociologi i alm.) uden biplaceringer. Bogen er helt utvetydigt ment som et bidrag til religionsvidenskabelig teoridannelse, og det er derfor også i dette tilfælde problematisk, at bogen ikke findes i gruppe 29.1. Men hertil kommer at placeringen i 16.3 må siges at være noget misvisende: Godt nok er kognitive teorier og metoder i dag ikke på samme måde i opposition til sociologien, som det var tilfældet i 50erne, hvor kognitionsforskningen i høj grad var at forstå som en reaktion på behaviorismen, men kognitive teorier har dog stadig et andet udgangspunkt end "sociologien i alm.", idet denne (sædvanligvis) tager udgangspunkt i sociale systemer (også, men ikke kun á la Luhmann), medens kognitionsforskningen fortsat tager udgangspunkt i det enkelte menneskes forudsætninger for tilegnelse af kompetence.

\section{Motivation og realisme}

Jeg skrev ovenfor at domæneanalyse burde have en betydelig ind ydelse på udvikling og design af informationssystemer, og at det i den sammenhæng er min opfattelse at filosofisk klassifikation og bibliografisk klassifikation bør være intimt forbundne. Opfattes filosofisk klassifikation som irrelevant i forbindelse med bibliografisk klassifikation kan dette kun være begrundet $\mathrm{i}$ at filosofisk klassifikation defineres som et projekt med „objektivt universalistiske“ prætentioner: Altså at filosofisk klassifikation ikke har noget med almindelige videnskabelig praksis at gøre, men blot refererer til en forældet og forladt filosofisk bestræbelse. I modsætning hertil opfatter jeg, som sagt, filosofisk klassifikation som en samlebetegnelse for diverse videnskabernes vi- 
densorganisationsformer, og dermed som en del af domæneanalysens naturlige afsæt.

Jeg skrev også, at jeg ville forholde mig kritisk til påstanden om videns subjektive natur. Viden er naturligvis subjektiv i den forstand at hvert enkelt subjekt besidder en viden (og en manglende viden), der er kendetegnende for lige netop dette subjekt og ikke andre. Viden er også subjektiv i den forstand, at en bruger i en konkret informationssøgningssituation står med et informationsbehov, der er lige netop denne brugers og ikke andres. Men det er langt fra sikkert at denne viden er relevant i forbindelse med design af informationssystemer. Informationssystemer er (bibliografiske) repræsentationer af situerethed, erfaringsområder og videnskabelige domoner, og disse er alle forankret i en social kontekst, og dermed ikke subjektive, men kollektive ${ }^{10}$. Giver en enkelt interviewet potentiel bruger udtryk for den subjektive vurdering, at kristendommen er den ideelle religion, og alle de andre blot ukomplette varianter, da er denne subjektive opfattelse så urealistisk i forhold til de aktuelle religionsvidenskabelige teorier og erfaringer, at det vil være misrepræsentation af domænet at lade denne opfattelse in uere på systemet. Man kan selvfølgelig argumentere for, at hvis et større antal af det givne systems formodede brugere går rundt med sådanne „teorier“ om religion, da vil det være yderst velbegrundet at konstruere systemet således at også denne brugergruppe let kan finde frem til bl.a. religionsvidenskabelig litteratur, der kan hjælpe dem til mere nuancerede og realistiske tentative svar på de spørgsmål de stiller, eksempelvis: Hvad er religion, egentlig? Men hertil er der (mindst) to ting at bemærke. For det første er denne viden eller rettere mangel på samme (om forholdet mellem kristendommen og andre religioner) ikke subjektiv. Det er den ikke i den simple betydning at der er ere om den. I den simple betydning at viden er bundet til en eller ere sociale sammenhænge, at den er bundet til nogle bestemte måder, hvorpå man taler om religion. Det anvendte eksempel på en opfattelse af forholdet mellem kristendommen og andre religioner er sandsynligvis ganske udbredt i dag, og som sådan er holdningen ikke subjektiv (individuelt enestående) men derimod situeret $i$ en social kontekst. Situeret i bestemte offentlige kommunikative og diskursive sammenhænge: Det er den opfattelse, der formidles af bl.a. Dansk Folkeparti og Den Danske Forening. Ingen brugeres viden eller mangel på samme - heller ikke de der ikke er tilknyttet et traditionelt domæne - er altså subjektiv, men derimod situeret $\mathrm{i}$ forskellige mere eller mindre velafgrænsede sociale sammenhænge. Alle disse sociale sammenhænge er relevante for domæneanalysen, i det et domæne ikke blot bør opfattes som et veletableret fagområde, men som en hvilken som helst social sammenhæng, der på meningsfuld måde lader sig afgrænse. Et universelt informationssystem skal altså reprcesentere på en sådan måde at såvel religionsforskere som medlemmer af Den Danske Forening kan anvende systemet. Heri ligger at viden er relativ i forhold til kontekst, men ikke at den er subjektiv.

En anden væsentlig grund til at være forbeholden overfor den opfattelse at viden er af subjektiv natur, er at man med det udgangspunkt kunne få den tanke at man med udgangspunkt i - i princippet kontekstuafhængige - psykologiske og eller kognitive studier ville kunne erhverve sig en viden om, hvordan mennesker tænker og klassificerer m.v., og dermed kunne generere en generel teori om informationssøgningsadfærd. En generel teori, der så igen ville kunne appliceres på tesauruskonstruktion og i det hele taget på det ideelle design af informationssystemer. Den interesse har tidligere været kendetegnende for kognitivt orienteret forskning også i LIS. I dag er situationen en noget anden i det kognitivt orienteret forskning - som illustreret ved eksempelvis Ingwersens $(1992,128 f)$ inddragelse af situeret klassifikation - interesserer sig for videns- og kompetencetilegnelse i en kontekst. Og det er da også bl.a. kognitivt orienterede forskere, der selv har leveret en del af argumenterne for at studier i ,generel" brugeradfærd har et yderst begrænset potentiale: I forbindelse med eksempelvis Dyirbal klassifikation argumenterede Lakoff, som anført, for at det er muligt på baggrund af antropologiske studier at ræsonnere sig frem til en række - som det påstås - universelle klassifikationsprincipper, som sammenkædningens 
princip, erfaringsområdets princip etc. Disse principper præsenteres som universelle, men det konkrete indhold i de enkelte klasser, den måde hvorpå de enkelte begreber er forbundne - den implicitte Dyirbal tesaurus - er domænespecifik og den eneste måde, hvorpå vi kan erhverve os viden om begrebernes konkrete relationer og om hvad der motiverer disse, er ved antropologiske studier henholdsvis domæneanalyse. Hos Dyirbal folket er fisk og fiskeredskaber i samme klasse, og det kan i henhold til ovenstående ikke overraske: En klasse der bl.a. indeholder fisk og fiskeredskaber er en klasse, der er situeret $\mathrm{i}$ en dagligdags erfaring. Men eksempelvis vand er ikke i denne klasse, hvilket det i henhold til situerethed og erfaring udmærket kunne have været: Man må gå udfra at en typiske Dyirbal fiskesituation sædvanligvis involverer vand. De nævnte universelle principper forklarer Dyirbal-klassifikationen, men de forudsiger ikke nøjagtigt hvad kategorierne vil indeholde (Lakoff, 1990, 21). Hvilke erfaringer, der er relevante for klassifikationen, er noget man må loere, og ikke noget man kan forudsige. Dyirbal folket (og os andre) må lære at fiskens element, vandet, ikke er relevant for klassifikationen. På nøjagtig samme måde er vi nødt til - ved domæneanalyse - at lære at „helligånder“ situeret i et teologisk begrebsunivers er forbundet med Faderen og Sønnen, medens (hellig-) ånder i et andet domæne klassificeres sammen med spøgelser, genfærd, medier etc. Vi er så at sige nødt til, hver eneste gang vi udvikler en skabelon for bibliografiske repræsentationer, at foretage en domæneanalyse af de filosofiske (implicitte og eksplicitte) klassifikationssystemer, der er gangbare i den aktuelle kontekst. Disse analyser foretages ved hjælp af diverse filosofiske, samfunds- og humanvidenskabelige metoder, og der er ingen grund til at tro, at det domæneanalytiske arbejde er noget, vi bliver færdige med i en overskuelig fremtid, om nogensinde.

\section{Noter}

1. Vi kan her genkende en tendens der også gør sig gældende i eksempelvis UDK og DK5: Grene af kristendommen (her den romersk-katolske kirke) får en klasse for stort set hvert tænkelige begreb (paven, søndagsskoler, Herrens dag etc.), medens 4 af verdens største religioner, der spreder sig ud over det meste af asien må nøjes med en enkelt klasse: 294.

2. Det vil f.eks. ofte være vanskeligt at beslutte hvornår et givent dokument bør klassificeres under ,paven“, og hvornår under ,,den romersk-katolske kirke“".

3. Monorepræsentation betegner her det modsatte af polyrepræsentation: Hvad Ingwersen $(1992,129)$ argumenterer for bl.a. kan opnås ved at kombinere categorial og situational klassifikation (se nedenfor) Ved polyrepræsentationelle metoder er det muligt at betjene brugere med forskellige erkendelsesinteresser, det forudsætter blot at der (poly-) repræsenteres (indekseres/klassificeres) i overensstemmelse med ere og ikke nødvendigvis kompatible erkendelsesinteresser.

4. Jeg refererer i denne korte skitse over antropologiens historie overvejende til D'Andrade (1995, 1-15). D'Andrade interesserer sig for kognitiv antropologi og inddeler antropologiens historie i en historisk, en funktionalistisk, og en kognitiv periode. Denne inddeling harmonerer fint med mine interesser, men den er i forhold til antropologien generelt lidt for simpel. For en god alternativ fremstilling se Baal, 1985.

5. Denne type eksperimenter er almindelige inden for såvel antropologien i almindelighed som inden for den kognitive antropologi i særdeleshed. Antropologien har en lang tradition for at beskæftige sig med i udgangspunktet slægtskabsstrukturer henholdsvis stamme/klanstrukturer, men siden hen diverse folketaksonomier i det hele taget, og i arbejdet med at identificere disse er procedurer á la Lurias ofte anvendt. For et godt overblik over diverse kognitive metoder, der involverer de af bl.a. Ingwersen på IR applicerede begreber som „multidimensional scaling“ og „polyrepresentation“ se D’ Andrade 1995, 31-91.

6. Fra og med 50erne er betegnelsen ,primitive“ kulturer i den antropologiske litteratur blevet er- 
stattet af betegnelsen ,skriftløse“ kulturer. En noget mere velvalgt term, idet den dels udtrykker en betegnende egenskab ved disse kulturer, og dels ved det at de nedladende under- og overtoner er forsvundet. Termen ,primitive“ "figurerer dog stadig i eksempelvis DK5 systematikken vedr. gruppe 29.9

7. I UDK er situationen tilsvarende.

8. Jeg læner mig i mit epistemologiske udgangspunkt tæt opad Armin W. Geertz $(2000,28)$ der kalder sin tilgang ikke-reproesentativ realisme: Realistisk fordi 1) den fysiske verden er uafhængig af vores viden om den, og fordi 2) i den udstrækning teorierne kan appliceres på virkeligheden, kan de det såvel indenfor som udenfor eksperimentelle situationer. Ikke-reprcesentativ i det der ikke inkorporeres nogen korrespondensteori om sandhed Det sidste forklares således at vore teoriers succes kan måles i forhold til i hvilken udstrækning de formår at gøre dele af verden mere forståelig for os, men også at vi ikke kan sige noget om i hvilken udstrækning de beskriver verden som den virkelig er, da vi ikke har adgang til nogen verden uafhængigt af vore teorier. Det vil sige at når jeg kalder én teori ugyldig, så gør jeg det naturligvis ikke fordi jeg har en viden der går bag om teorier, men med udgangspunkt i en anden teori.

9. Jeg mener ikke Sociale systemer burde yttes til $29.1 \mathrm{og}$ end ikke have en biplacering her. Men jeg mener - i overensstemmelse med Hjørlands domæneteori - at værket burde indekseres i henhold til sine ,erkendelsespotentialer“. Og disse erkendelsespotentialer er i DK5 sammenhæng også knyttet til religionsvidenskaben. Sociale systemer har følgende kontrollerede emneord „sociologisk teori“, ,,autopoesis“, „systemteori“, „samfundsteori“, „,sociologi““. Disse er rimelige, men de er for snævre og for få.

10. Jeg trækker i denne fremstilling af kollektiv versus subjektiv viden store veksler på Hjørland (1991; 1993, 127f)

\section{Referencer}

Baal, J. van \& Beek, W.E.A van (1985). Symbols for Communication. An Introduction to the Anthropological Study of Religion. Van Gorcum, Assen.

Borges, J.L (1990). John Wilkins' analytiske sprog. Almen semiotik 2, 1990: 11-14.

D’Andrade, Roy (1995). The Development of Cognitive Anthropology. Cambridge University Press.

Dixon, R.M.W (1968). The Dyirbal Language of North Queensland. London 1968.

Geertz, Armin W (2000). Analytical Theorizing in the Secular Study of Religion. Secular Theories of Religion. Current Perspectives. Ed. Tim Jensen \& Michael Rothstein. Museum Tusculanum Press: 2131 .

Graarup, Kasper (2001) Religionsvidenskab på folkebiblioteket. Totem Særnummer 2001: 23-39

Grauballe, H. \& Kaae S. \& Lykke, M. \& Mai, J-E (1998). Skriftserie i Klassifikation; 1: Klassifikationsteori. 2.udgave, Danmarks Biblioteksskole.

Hjørland, Birger (1991). Det kognitive paradigme i biblioteks- og informationsvidenskaben. Biblioteksarbejde 33: 5-37.

Hjørland, Birger (1993). Emnereprcesentation og informationssøgning. Bidrag til en teori på et kundskabsteoretisk grundlag. Valfrid. Göteborg.

Ingwersen, Peter (1992). Information Retrieval Interaction, Graham Taylor, LA.

Klausen, Bodil (1999). Religion og kognition. Aarhus Universitetsforlag.

Kristensen, Ragnhild (1987). Religiøse minoriteter. Red. Ragnhild Kristensen \& Ole Riis. Aarhus Universitetsforlag.

Lakoff, George (1987). Women, Fire and Danger- 
ous Things. What Categories Reveal about the Mind. University of Chicago Press.

Lakoff, George (1990). Klassifikatorer som afspejling af tanken. Almen Semiotik 2, 1990: 15-23.

Luhmann, Niklas (2000). Sociale systemer. Grundrids til en almen teori. Hans Reitzel, Kbh.
Luria, A.R (1976).Cognitive Developments: Its Cultural and social foundations. Harvard University Press.

Paden, W.E (1992). Interpreting the Sacred. Ways of Viewing Religion. Beacon Press. Boston.

Rothstein, Mikael (2000). UFOer og rumvasener: Myten om de flyvende tallerkener. Gyldendal, Kbh 